TITLE:

\title{
The delayed effects of monetary shocks in a two-sector New Keynesian model
}

$\operatorname{AUTHOR}(\mathrm{S}):$

Katayama, Munechika; Kim, Kwang Hwan

\section{CITATION:}

Katayama, Munechika ...[et al]. The delayed effects of monetary shocks in a two-sector New Keynesian model. Journal of Macroeconomics 2013, 38(Part B): 243-259

ISSUE DATE:

2013-12

URL:

http://hdl.handle.net/2433/179790

\section{RIGHT:}

(c) 2013 Elsevier Inc.; この論文は出版社版でありません。引用の際には 出版社版をご確認ご利用ください。; This is not the published version. Please cite only the published version. 


\title{
The Delayed Effects of Monetary Shocks in a Two-sector New Keynesian Model ${ }^{*}$
}

\author{
Munechika Katayama \\ Kyoto University \\ katayama@econ.kyoto-u.ac.jp
}

\author{
Kwang Hwan Kim \\ Yonsei University \\ kimkh01@yonsei.ac.kr
}

August 6, 2013

\begin{abstract}
This paper studies a two-sector New Keynesian model that captures the hump-shaped response of non-durable and durable spending to a monetary shock when non-durable prices are sticky and durable goods are flexibly priced. Based on the estimated parameters, we show that habit formation and investment adjustment costs are not sufficient to generate the gradual response of non-durable and durable spending in this setup. We find that nominal wage rigidity and non-separable preferences between consumption and labor are also necessary to delay the peak response of non-durable and durable spending in the estimated two-sector New Keynesian model.
\end{abstract}

JEL Classification: E21, E30, E31, E32

Keywords: Sticky Prices; Sticky Wages; Non-Separable Preferences; Two-sector New Keynesian Model

${ }^{*}$ We thank the seminar participants at the Bank of Japan for their comments and Joonseok Oh for his excellent research assistance. 


\section{Introduction}

A key feature of the monetary policy transmission is that each component of aggregate spending exhibits a gradual hump-shaped response to a monetary shock. The response of non-durable goods spending to an expansionary monetary shock reaches its maximal impact about one year after the shock rather than immediately. This empirical regularity has been emphasized in many studies using identified vector autoregression (VAR), including Christiano, Eichenbaum, and Evans $(1996,2005)$ and Leeper, Sims, and Zha (1996). The inclusion of habit formation in the consumer's utility function to a standard New Keynesian model has been considered as the key to matching the hump-shaped response of non-durable goods to the monetary shock (see, e.g., Fuhrer, 2000). Consumer durable spending and residential investment also exhibit a delay in the peak response to a monetary shock in recent VAR studies by Erceg and Levin (2006) and Monacelli (2009). Christiano, Eichenbaum, and Evans (2005) show that the adjustment costs of changing investment are essential to a New Keynesian model to replicate the gradual hump-shaped response of investment to the monetary shock.

However, the success of the New Keynesian model on the spending side has been obtained in onesector models where all prices are equally sticky. In other words, previous New Keynesian models have successfully unveiled the source of the hump-shaped response under the assumption of symmetric price rigidity across sectors. Barsky, House, and Kimball (2007) stress the importance of allowing for differing degrees of price stickiness across sectors in a New Keynesian model. In particular, they demonstrate that the inclusion of flexibly priced durable goods dramatically changes the dynamics of the model in response to the monetary shock. Barsky, House, and Kimball (2007) present arguments for why durable goods prices might be much more flexible than non-durable goods prices. First, housing is relatively expensive on a per-unit basis; therefore, if menu costs have important fixed components, there is a large incentive to negotiate the price of this good. Second, most homes are priced for the first time when they are sold. Kim and Katayama (2013) also find that flexible durable prices are supported by the data in their estimated two-sector New Keynesian model.

This paper seeks to uncover the source of the gradual hump-shaped response of non-durable and durable spending to a monetary shock in a two-sector New Keynesian model where non-durable prices are sticky and durable goods are flexibly priced. To this end, we construct and estimate a model that features habit formation, investment adjustment costs, sticky nominal wages, and non-separable preferences between consumption and labor. 
We show that habit formation and durable investment adjustment costs are not sufficient to generate the pronounced hump-shaped responses of non-durable and durable spending to the monetary shock when we allow for the flexibly priced durable sector in the two-sector New Keynesian model. In addition to these two elements, we find that nominal wage rigidity and non-separable preferences are necessary to produce a substantial delay in the peak responses of non-durable and durable spending in the two-sector New Keynesian model with flexibly priced durable goods. To be more specific, non-separable preferences and sticky wages complement the habit formation in non-durable consumption. While habit formation alone only generates one quarter of delay in the peak response of non-durable consumption in our estimated twosector New Keynesian model, they generate a significant further delay in the peak response of non-durable consumption. More importantly, sticky wages exert a significant impact on the response of durable spending in the two-sector New Keynesian model, such that investment adjustment costs should be coupled with sticky wages to produce a hump-shaped response of durable spending. Otherwise, investment adjustment costs alone produce a counterfactual delayed response of durable spending.

Several papers have introduced sticky wages and non-separable preferences into a two-sector New Keynesian model with flexibly priced durable goods and estimated it using a Bayesian method. However, they abstract either from habit formation or investment adjustment costs and focus solely on how sticky wages and non-separable preferences generate the comovement between non-durable and durable spending in response to a monetary shock. ${ }^{1}$ For example, Iacoviello and Neri (2010) demonstrate the importance of sticky wages and Kim and Katayama (2013) show the importance of non-separable preferences in capturing the comovement between non-durable and durable spending. The present paper emphasizes the additional role that sticky wages and non-separable preferences play in generating the hump-shaped response of nondurable and durable spending to the monetary shock.

Our work is most closely related to the paper by Carlstrom and Fuerst (2010). They also investigate the role of sticky wages together with habit formation and investment adjustment costs in shaping the response of non-durable and durable spending to a monetary shock in the two-sector New Keynesian model with flexibly priced durable goods. However, our paper differs from theirs in two respects. First, while Carlstrom and Fuerst (2010) calibrate their model, we take our model to the data by estimating it by a Bayesian approach. Second, they only consider separable preferences, but we use the more general King-Plosser-Rebelo preferences that nest both non-separable and separable preferences and analyze the

\footnotetext{
${ }^{1}$ If wages are flexible and preferences are separable, as Barsky, House, and Kimball (2007) demonstrate, the comovement problem arises in response to a monetary shock in a two-sector sticky price model with flexibly priced durable goods: an expansionary monetary policy leads to an increase in non-durable goods production but a decline in durable goods production.
} 
role of non-separable preferences.

The rest of the paper is organized as follows. Section 2 presents our two-sector New Keynesian model with sticky non-durable goods prices and flexibly priced durable goods. Our model incorporates standard ingredients to generate the hump-shaped responses of non-durable and durable spending. In Section 3, we take our model to the data to determine the factors that account for the delayed effect of the monetary policy shocks observed in empirical studies. We estimate four different specifications and analyze which elements are quantitatively important for the hump-shaped responses. Finally, Section 4 concludes.

\section{The Model}

In this section, we extend the two-sector sticky price model of Barsky, House, and Kimball $(2003,2007)$ by incorporating habit formation in non-durable goods, durable investment adjustment costs, sticky wages, and non-separability between aggregate consumption and labor.

The economy is populated by a continuum of infinitely-lived households, an employment agency, a continua of firms in the two sectors that respectively produce differentiated non-durable and durable goods, perfectly competitive final goods firms in the two sectors, and a monetary authority.

\subsection{Households}

There is a continuum of households, indexed by $i \in[0,1]$. Households are identical except for the heterogeneity of labor. Each household $i$ is the supplier of its differentiated labor to the labor aggregator and has monopoly power over its own labor, and hence, it sets a wage for its differentiated labor.

The household receives utility from the consumption of non-durable goods, durable services, and leisure. The household's current utility depends on current consumption relative to a habit stock determined by the household's own past consumption. The household also enjoys the service flow from durable goods and incurs the disutility of hours worked. Following the literature, it is assumed to be proportional to a predetermined stock of the durable goods. ${ }^{2}$ Let $C_{i, t}$ and $D_{i, t-1}$ respectively denote period $t$ consumption of the non-durable goods and the predetermined durable stock, and let $L_{i, t}$ denote the labor supply. The typical household $i$ maximizes the expected lifetime utility, given by

$$
U_{i, 0}=E_{0}\left[\sum_{t=0}^{\infty} \beta^{t} b_{t} U\left(C_{i, t}-\gamma C_{i, t-1}, D_{i, t-1}, L_{i, t}\right)\right],
$$

\footnotetext{
${ }^{2}$ Without loss of generality, the coefficient of proportionality is normalized to 1 .
} 
where $\beta \in(0,1)$ is the subjective discount factor, $b_{t}$ is a discount factor shock (intertemporal preference shock), and $\gamma$ is the degree of habit in non-durable goods consumption. The intertemporal preference shock is a common ingredient in estimated DSGE models and follows the stochastic processes:

$$
\log b_{t}=\rho_{b} \log b_{t-1}+\xi_{b, t}
$$

where $\xi_{b, t} \sim N\left(0, \sigma_{\xi_{b}}^{2}\right)$.

We modify the conventional King-Plosser-Rebelo monetary utility function used by Basu and Kimball (2002) and Shimer (2009) to include the habit in non-durable goods, and the consumption of the service flow from durable goods. The specific form of $U(\cdot)$ adopted in this paper is

$$
U\left(C_{i, t}-\gamma C_{i, t-1}, D_{i, t-1}, L_{i, t}\right)=\frac{Z_{i, t}^{1-\frac{1}{\sigma}}\left(1+\left(\frac{1}{\sigma}-1\right) v\left(L_{i, t}\right)\right)^{\frac{1}{\sigma}}-1}{1-\frac{1}{\sigma}},
$$

where $Z_{i, t}=\left(\psi_{c}\left(C_{i, t}-\gamma C_{i, t-1}\right)^{1-\frac{1}{\rho}}+\psi_{d} D_{i, t-1}^{1-\frac{1}{\rho}}\right)^{\frac{\rho}{\rho-1}}$ and $v\left(L_{i, t}\right)=\phi \frac{\eta}{1+\eta} L_{i, t}^{\frac{\eta+1}{\eta}} \cdot Z_{i, t}$ is a quantity index that aggregates the consumption of non-durable goods and durable services, and $v\left(L_{i, t}\right)$ measures the disutility incurred from hours worked with $v^{\prime}>0, v^{\prime \prime}>0$.

In Eq. (3), the degree of non-separability is controlled by a parameter for the intertemporal elasticity of substitution, $\sigma$. The lower this parameter is, the larger the non-separability displayed by the utility function. The separable case, for instance, corresponds to $\sigma \rightarrow 1$ :

$$
\lim _{\sigma \rightarrow 1} U\left(C_{i, t}-\gamma C_{i, t-1}, D_{i, t-1}, L_{i, t}\right)=\log \left(Z_{i, t}\right)-v\left(L_{i, t}\right)
$$

Purchases of new durable goods (i.e., durable investment) increases the household's durable stock according to

$$
D_{i, t}=F\left(X_{i, t}, X_{i, t-1}\right)+(1-\delta) D_{i, t-1}
$$

where durable investment adjustment costs are given by

$$
F\left(X_{i, t}, X_{i, t-1}\right)=X_{i, t}\left[1-S\left(\frac{X_{i, t}}{X_{i, t-1}}\right)\right]
$$

Here, $\delta$ denotes the physical rate of depreciation. The function $S(\cdot)$ represents the adjustment costs incurred when the level of durable spending changes over time. We assume that $S(1)=0, S^{\prime}(1)=0$ so that there are 
no adjustment costs in the steady state and that $\kappa \equiv S^{\prime \prime}(1)>0$. Christiano, Eichenbaum, and Evans (2005) argue that this form of adjustment costs is better at replicating the hump-shaped response of investment in the one-sector sticky price model than the specifications in Lucas and Prescott (1971), Abel and Blanchard (1983), and Hayashi (1982).

The household enters period $t$ with the stock of private one-period nominal bonds $B_{i, t-1}$. During this period, the household receives wages, dividends paid by firms, and interest payments on bond holdings. These resources are used to purchase non-durable and durable goods, to acquire assets to be carried over to the next period, and to pay the costs of adjusting nominal wages. Then, the household's budget constraint (in nominal terms) is

$$
P_{c, t} C_{i, t}+P_{x, t} X_{i, t}+B_{i, t}+\mathrm{AC}_{i, t}^{W} \leq W_{i, t} L_{i, t}+\Pi_{i, t}+\epsilon_{t}^{r}\left(1+i_{t-1}\right) B_{i, t-1}
$$

where the subscripts $c$ and $x$ denote variables that are specific to the non-durable and durable sectors, respectively. $P_{c, t}$ and $P_{x, t}$ are the nominal prices of the non-durable and durable goods, $W_{i, t}$ is the nominal wage rate, $\mathrm{AC}_{i, t}^{W}$ is the costs of adjusting nominal wages, $\Pi_{i, t}$ is the profits returned to the consumer through dividends, $i_{t}$ is the nominal interest rate, and $\epsilon_{t}^{r}$ is an exogenous premium in the return to bonds.

We follow Kim (2000) by modeling nominal wage rigidity through the cost of adjusting nominal wages instead of applying the Erceg, Henderson, and Levin (2000) mechanism of Calvo sticky wages. The Calvo-style sticky wages complicate the solution of the model when preferences are non-separable between consumption and labor. However, wage adjustment costs are easily applicable regardless of separability. In other words, the degree of heterogeneity across households resulting from differing labor supplies, which are due to non-separable preferences, is significantly increased once preferences are non-separable. Each household would choose a different level of non-durable consumption, hours worked, and durable spending. To get around this issue, we adopt a quadratic adjustment cost of nominal wages, which allows for a symmetric equilibrium. The wage adjustment cost function is assumed to be quadratic and zero at the steady state. The nominal total adjustment cost for a household $i$ is given by

$$
\mathrm{AC}_{i, t}^{W}=\frac{\phi_{w}}{2}\left(\frac{W_{i, t}}{W_{i, t-1}}-1\right)^{2} W_{i, t}
$$

where $\phi_{w}$ is the wage adjustment cost parameter.

Finally, an exogenous premium in the return to bonds $\epsilon_{t}^{r}$ reflects inefficiencies in the financial sector leading to some premium on the deposit rate versus the risk free rate set by the central bank or to a risk 
premium that households require to hold the one period bond. $\epsilon_{r, t}$ follows the stochastic process:

$$
\log \epsilon_{r, t}=\rho_{\epsilon_{r}} \log \epsilon_{r, t-1}+\xi_{\epsilon_{r, t}}
$$

where $\xi_{\epsilon_{r, t}} \sim N\left(0, \sigma_{\xi_{\epsilon_{r}}}^{2}\right)$.

\subsection{Employment Agency}

The employment agency purchases the differentiated labor input supplied by each household. A large number of competitive employment agencies combine this specialized labor into a homogenous labor input, which is sold to intermediate goods firms according to

$$
L_{t}=\left[\int_{0}^{1} L_{i, t}^{\frac{\varepsilon_{w, t}-1}{\varepsilon_{w, t}}} d i\right]^{\frac{\varepsilon_{w, t}}{\varepsilon_{w, t}-1}} .
$$

Here, $L_{t}$ is the amount of the composite labor supplied by the aggregator, $L_{i, t}$ is the labor supply of household $i$ and $\varepsilon_{w, t}$ is the elasticity of substitution.

The first-order condition for profit maximization yields the demand function of each household's differentiated labor:

$$
L_{i, t}=\left(\frac{W_{i, t}}{W_{t}}\right)^{-\varepsilon_{w, t}} L_{t}
$$

where $W_{i, t}$ is the nominal wage of household $i$ and $W_{t}$ is the aggregate nominal wage index.

The desired markup of wages over the household's marginal rate of substitution is defined as $\mu_{w, t}=\frac{\varepsilon_{w, t}}{\varepsilon_{w, t}-1}$ and follows the exogenous stochastic process. As in Smets and Wouters (2007), the process for $\mu_{w, t}$ is assumed to be

$$
\log \mu_{w, t}=\left(1-\rho_{\mu_{w}}\right) \log \mu_{w}+\rho_{\mu_{w}} \log \mu_{w, t-1}+\xi_{\mu_{w}, t}-\theta \xi_{\mu_{w}, t-1},
$$

where $\xi_{\mu_{w}, t} \sim N\left(0, \sigma_{\xi_{\mu_{w}}}^{2}\right)$.

\subsection{Firms}

We assume the existence of a continuum of monopolistically competitive firms, indexed by $s \in[0,1]$, which produce differentiated intermediate goods in each sector. A final good in each sector is produced by a perfectly competitive representative firm. The firm produces the final good by combining a continuum of 
intermediate goods.

\subsubsection{Final goods firms}

The final good in each sector is aggregated by the constant elasticity of substitution (CES) technology:

$$
C_{t}=\left[\int_{0}^{1} C_{t}(s)^{\frac{\varepsilon_{c, t}-1}{\varepsilon_{, t}}} d s\right]^{\frac{\varepsilon_{c}, t}{\varepsilon_{c, t}-1}} \quad \text { and } \quad X_{t}=\left[\int_{0}^{1} x_{t}(s)^{\frac{\varepsilon_{x, t}-1}{\varepsilon_{x, t}}} d s\right]^{\frac{\varepsilon_{x, t}}{\varepsilon_{x, t}-1}},
$$

where $c_{t}(s)$ and $x_{t}(s)$ are the quantity of intermediate goods $s$ used as an input in each sector.

The elasticity of substitution of intermediate goods in sector $j=c, x$ is $\varepsilon_{j, t}$ and $\mu_{j, t}=\frac{\varepsilon_{j, t}}{\varepsilon_{j, t}-1}$ is the desired mark-up of price over marginal cost for intermediate goods firms in each sector $j=c, x$. The process for $\mu_{j, t}$ is given by

$$
\log \mu_{j, t}=\left(1-\rho_{\mu_{j}}\right) \log \mu_{j}+\rho_{\mu_{j}} \log \mu_{j, t-1}+\xi_{\mu_{j, t}}
$$

where $\xi_{\mu_{j}, t} \sim N\left(0, \sigma_{\xi_{\mu_{j}}}^{2}\right)$ for $j=c, x$.

A cost minimization problem for the final good producer in each sector implies that the demand for intermediate goods is given by

$$
c_{t}(s)=\left(\frac{p_{c, t}(s)}{P_{c, t}}\right)^{-\varepsilon_{c, t}} C_{t} \quad \text { and } \quad x_{t}(s)=\left(\frac{p_{x, t}(s)}{P_{x, t}}\right)^{-\varepsilon_{x, t}} X_{t}
$$

where $p_{j, t}(s)$ is the price of intermediate good $s$ in sector $j=c, x$ and $P_{j, t}$ is the aggregate price level in sector $j=c, x$. Finally, the zero-profit condition implies that the sectoral price index is expressed as

$$
P_{j, t}=\left[\int_{0}^{1} p_{j, t}(s)^{1-\varepsilon_{j, t}} d s\right]^{\frac{1}{1-\varepsilon_{j, t}}} \text { for } \quad j=c, x
$$

\subsubsection{Intermediate goods firms}

Intermediate good producers in each sector are monopolistically competitive. Each intermediate goods firm produces its differentiated goods using the following production function:

$$
\begin{gathered}
c_{t}(s)=A_{t} l_{c, t}(s), \\
x_{t}(s)=A_{t} A_{x, t} l_{x, t}(s),
\end{gathered}
$$


where $A_{t}$ is an aggregate total factor productivity (TFP) shock, $A_{x, t}$ is a sectoral TFP shock in the durable goods sector, and $l_{j, t}(s)$ is the labor in firms $s$ in sector $j=c, x$ at time $t$. We assume that these aggregate and sectoral technology shocks follow the stochastic processes:

$$
\begin{aligned}
\log \left(A_{t}\right) & =\rho_{A} \log \left(A_{t-1}\right)+\xi_{t}, \\
\log \left(A_{x, t}\right) & =\rho_{A_{x}} \log \left(A_{x, t-1}\right)+\xi_{x, t},
\end{aligned}
$$

where $\xi_{t} \sim N\left(0, \sigma_{\xi}^{2}\right)$ and $\xi_{x, t} \sim N\left(0, \sigma_{\xi_{x}}^{2}\right)$.

Intermediate goods firms are assumed to set nominal prices in a staggered fashion according to the stochastic time dependent rule proposed by Calvo (1983). Each firm in sector $j=c, x$ resets its price with the probability of $1-\theta_{j}$ each period, independently of the time elapsed since the last adjustment. Thus, a fraction $\theta_{j}$ of firms cannot re-optimize their prices and therefore set their prices following the indexation rule

$$
p_{j, t}(s)=\pi_{j, t-1}^{\iota_{j}} p_{j, t-1}(s), \quad j=c, x,
$$

where $\pi_{j, t}=P_{j, t} / P_{j, t-1}$. However, an intermediate goods firm resetting its price in period $t$ in sector $j=c, x$ will seek to maximize the present value of the expected future real profits generated while that price remains effective,

$$
E_{0}\left[\sum_{t=0}^{\infty} \beta^{t} \theta_{j}^{t} \gamma_{j, t} \frac{\Pi_{j, t}}{P_{j, t}}\right],
$$

subject to the sequence of demand constraints (14). Here, $\gamma_{j, t}$ is the shadow value of the good produced in sector $j$ and $\Pi_{j, t} / P_{j, t}$ measures the real value of an intermediate goods firm's profit in sector $j$ in period $t$. It is straightforward to show that the optimal reset prices in sector $j=c, x$, denoted as $p_{j, t}^{*}$, are

$$
p_{c, t}^{*}=\mu_{c, t} \frac{E_{t} \sum_{k=0}^{\infty} \beta^{k} \theta_{c}^{k}\left(\frac{\zeta_{c, t+k}}{P_{c, t+k}}\right)\left(P_{c, t+k}\right)^{\varepsilon_{c, t}} \gamma_{c, t+k} C_{t+k}}{E_{t} \sum_{k=0}^{\infty} \beta^{k} \theta_{c}^{k}\left(P_{c, t+k}\right)^{\varepsilon_{c, t}-1} \gamma_{c, t+k} C_{t+k}}
$$

and

$$
p_{x, t}^{*}=\mu_{x, t} \frac{E_{t} \sum_{k=0}^{\infty} \beta^{k} \theta_{x}^{k}\left(\frac{\zeta_{x, t+k}}{P_{x, t+k}}\right)\left(P_{x, t+k}\right)^{\varepsilon_{x, t}} \gamma_{x, t+k} X_{t+k}}{E_{t} \sum_{k=0}^{\infty} \beta^{k} \theta_{x}^{k}\left(P_{x, t+k}\right)^{\varepsilon_{x, t}-1} \gamma_{x, t+k} X_{t+k}},
$$

where $\zeta_{j, t}$ is the nominal marginal cost in sector $j$. Finally, the equation describing the dynamics for the aggregate price level in sector $j=c, x$ is given by $P_{j, t}=\left[\left(1-\theta_{j}\right)\left(p_{j, t}^{*}\right)^{1-\varepsilon_{j, t}}+\theta_{j}\left(\pi_{j, t-1}^{l_{j}} P_{j, t-1}\right)^{1-\varepsilon_{j, t}}\right]^{\frac{1}{1-\varepsilon_{j, t}}}$. 


\subsection{Symmetric Equilibrium, Market Clearing, and Monetary Authority}

We assume a symmetric equilibrium to rule out potential multiple equilibria in which identical agents behave differently because of different initial conditions. In a symmetric equilibrium, each household is endowed with the same initial condition and makes an identical decision so that $C_{i, t}=C_{t}, L_{i, t}=L_{t}, X_{i, t}=X_{t}$, and $B_{i, t}=B_{t}$.

In the equilibrium, the net private debt $B_{t}=0$ and the labor market equilibrium requires

$$
L_{t}=L_{c, t}+L_{x, t}
$$

where $L_{j, t}=\int l_{j, t}(s) d s$ is the labor used in sector $j=c, x$.

The monetary authority conducts monetary policy using the short-term nominal interest rate as the policy instrument. The gross nominal interest rate $R_{t}^{n} \equiv 1+i_{t}$ follows a Taylor rule of the following type:

$$
R_{t}^{n}=\left(R^{n}\right)^{\left(1-\rho_{R}\right)}\left(R_{t-1}^{n}\right)^{\rho_{R}}\left(\pi_{t}\right)^{\rho_{\pi}\left(1-\rho_{R}\right)}\left(Y_{t}^{z}\right)^{\rho_{Y}\left(1-\rho_{R}\right)} \exp \left(\xi_{R, t}\right),
$$

where $\xi_{R, t} \sim N\left(0, \sigma_{\xi_{R}}^{2}\right)$ is a monetary policy shock, $\pi_{t}$ is an economy-wide inflation rate, and $Y_{t}^{z}$ is the deviation of the real GDP from its steady state.

The economy-wide total output (real GDP) $Y_{t}$ is given by

$$
Y_{t}=\frac{P_{c, t}}{P_{t}} C_{t}+\frac{P_{x, t}}{P_{t}} X_{t}
$$

where $P_{t}$ is the aggregate price index (GDP deflator). Following Erceg and Levin (2006), we define the aggregate price index $P_{t}$ as

$$
P_{t}=P_{c, t}^{\omega_{c}} P_{x, t}^{1-\omega_{c}}
$$

where $\omega_{c}$ is the steady state output share of the non-durable goods sector. This aggregate price index $P_{t}$ is used to calculate the economy-wide inflation rate.

\section{Bayesian Estimation}

In this section, we will take our model to the data to determine the elements of the model that are important in delaying the peak response of non-durable and durable spending to the monetary shocks observed in 
empirical studies. To this end, we employ a Bayesian approach.

\subsection{Data}

In our estimation, we include the following seven observables, which are related to the model variables through the measurement equations as follows.

$$
\begin{aligned}
d c_{t} & \equiv \log \left(\frac{C_{t}}{C_{t-1}}\right)=\text { Per capita non-durable consumption growth }=\hat{C}_{t}-\hat{C}_{t-1} \\
d x_{t} & \equiv \log \left(\frac{X_{t}}{X_{t-1}}\right)=\text { Per capita durable consumption growth }=\hat{X}_{t}-\hat{X}_{t-1} \\
\pi_{c, t} & \equiv \log \left(\frac{P_{c, t}}{P_{c, t-1}}\right)=\text { Non-durable price inflation }=\hat{\pi}_{t}^{c} \\
\pi_{x, t} & \equiv \log \left(\frac{P_{x, t}}{P_{x, t-1}}\right)=\text { Durable price inflation }=\hat{\pi}_{t}^{x} \\
h_{t} & \equiv \log \text { per capita hours worked }=\hat{L}_{t} \\
d w_{t} & \equiv \log \left(\frac{w_{t}}{w_{t-1}}\right)=\text { Real wage growth }=\hat{W}_{t}-\hat{W}_{t-1} \\
f f_{t} & \equiv \text { Federal funds rate (quarterly rate) }=\hat{R}_{t}^{n}
\end{aligned}
$$

Here, variables with a hat are log deviations from the steady-state values.

Following Kim and Katayama (2013), we define the non-durable consumption expenditure as the sum of non-durables and services, excluding expenditures on housing and utility, which are presumably necessary for enjoying the stock of durable goods. Durable consumption expenditure consists of consumer durable spending, housing and utility expenditure, and residential investment. Based on these definitions, we construct $d c_{t}, d x_{t}, \pi_{c, t}$, and $\pi_{x, t}$ using data from the NIPA tables. The detailed procedures of constructing these variables are explained in the Appendix of Kim and Katayama (2013).

We also retrieve the effective Federal funds rate (FEDFUNDS), Hours of All Persons (Nonfarm Business Sector, HOANBS), Compensation Per Hour (Nonfarm Business Sector, COMPNFB), GDP deflator (GDPDEF), and Total Population (POP) from FRED of the Federal Reserve Bank of St. Louis. The monthly Federal funds rate is converted to quarterly observations by taking the quarterly averages. The annualized percentage Federal funds rate is converted to a quarterly rate (decimal number) by dividing it by 400 . We deflate the nonfarm business sector compensation per hour by the GDP deflator to get the real wage index. The monthly population data are converted to quarterly data by taking the end-of-quarter observations. All of these data are demeaned. The sample period is from 1959:Q2 to 2010:Q4. 
Table 1: Parameters and Prior Distributions

\begin{tabular}{cllcc}
\hline Parameter & Description & Distribution & Mean & Std. Dev. \\
\hline $1 / \sigma$ & Inverse of intertemporal elasticity of substitution & Normal & 1.50 & 0.37 \\
$\rho$ & Elasticity of substitution between non-durable and durable & Normal & 1.17 & 0.1 \\
$\gamma$ & Habit parameter for non-durable consumption & Gamma & 0.7 & 0.1 \\
$\psi$ & Durable investment adjustment cost parameter & Gamma & 4 & 1 \\
$\iota_{c}$ & Degree of partial indexation for non-durable firms & Beta & 0.5 & 0.15 \\
$\phi_{w}$ & Wage adjustment cost parameter & Gamma & 50 & 20 \\
$\rho_{A}$ & Persistence of aggregate productivity shock & Beta & 0.7 & 0.2 \\
$\rho_{A_{x}}$ & Persistence of durable-specific technology shock & Beta & 0.5 & 0.2 \\
$\rho_{R}$ & Interest smoothing coefficient in the Taylor rule & Beta & 0.5 & 0.2 \\
$\rho_{\pi}$ & Coefficient on the inflation rate in the Taylor rule & Gamma & 2 & 0.25 \\
$\rho_{Y}$ & Coefficient on the output gap in the Taylor rule & Gamma & 0.2 & 0.2 \\
$\rho_{b}$ & Persistence of discount factor shock & Beta & 0.5 & 0.2 \\
$\rho_{\epsilon_{r}}$ & Persistence of risk premium shock & Beta & 0.5 & 0.2 \\
$\rho_{\mu_{w}}$ & Persistence of wage markup shock & Beta & 0.5 & 0.2 \\
$\theta$ & MA parameter in wage markup shock & Beta & 0.5 & 0.2 \\
$\rho_{\mu_{c}}$ & Non-durable price markup shock & Beta & 0.5 & 0.2 \\
$\rho_{\mu_{x}}$ & Durable price markup shock & Beta & 0.5 & 0.2 \\
$\sigma_{\xi}$ & Std. Dev. of aggregate technology shock & Inverse Gamma & 0.1 & 2 \\
$\sigma_{\xi_{x}}$ & Std. Dev. of sectoral technology shock in durable & Inverse Gamma & 0.1 & 2 \\
$\sigma_{\xi_{R}}$ & Std. Dev. of monetary policy shock & Inverse Gamma & 0.1 & 2 \\
$\sigma_{\xi_{b}}$ & Std. Dev. of discount factor shock & Inverse Gamma & 0.1 & 2 \\
$\sigma_{\xi_{r}}$ & Std. Dev. of risk premium shock & Inverse Gamma & 0.1 & 2 \\
$\sigma_{\xi_{\mu_{w}}}$ & Std. Dev. of wage markup shock & Inverse Gamma & 0.1 & 2 \\
$\sigma_{\xi_{\mu_{c}}}$ & Std. Dev. of non-durable price markup shock & Inverse Gamma & 0.1 & 2 \\
$\sigma_{\xi_{\mu_{x}}}$ & Std. Dev. of durable price markup shock & Inverse Gamma & 0.1 & 2 \\
\hline
\end{tabular}

While we have seven observable variables, there are eight structural shocks in the model (aggregate and durable sector-specific technology shocks, a discount factor shock, a risk-premium shock, two price markup shocks, a wage markup shock, and a monetary policy shock). Thus, the stochastic singularity problem is not an issue here (i.e., the number of shocks is greater than the number of structural shocks).

\subsection{Prior Distributions}

Based on Barsky, House, and Kimball (2007), we impose the following parameter values to make our specification comparable to theirs. We use $\beta=1.02^{-0.25}$ and $\delta=0.0125$, which makes the annual discount rate $2 \%$ and the depreciation rate $5 \%$ per year. We set $\eta$ to 1 , which corresponds to the Frisch labor supply elasticity when preferences are separable (i.e., $\sigma \rightarrow 1$ ). The values of $\varepsilon_{c}$ and $\varepsilon_{x}$ are set equal to 11 so that the steady-state markup becomes $10 \%$ in both the non-durable and durable sectors. Finally, setting $\omega_{c}=0.75$ results in the non-durable sector accounting for $75 \%$ of GDP in a steady state.

Furthermore, we set $\varepsilon_{w}=7.67$, implying a steady state wage markup of $15 \%$. We impose the Calvo parameters such that we have a sticky-price non-durable sector and a flexible-price durable sector. Specifi- 
cally, we set $\theta_{c}=2 / 3$ and $\theta_{x}=0$. This corresponds to the case in which the comovement problem arises in Barsky, House, and Kimball (2007). Iacoviello and Neri (2010) also assume sticky non-durable prices and flexible durable prices. Kim and Katayama (2013) find that in a very similar setup, the data decisively prefer flexible durable prices. Since durable goods are assumed to be flexibly priced, we set $\iota_{x}=0$ so that there is no partial indexation in the durable sector.

Table 1 summarizes the parameters to be estimated and the associated prior distributions. Unless otherwise stated, most of the prior distributions are adopted from Smets and Wouters (2007). The prior distribution for $1 / \sigma$, which is an inverse of the intertemporal elasticity of substitution, is centered at 1.5 . The prior mean for $\rho$, which is the elasticity of substitution between non-durable and durable consumption, is set to be 1.17 based on the GMM estimate and the corresponding standard error in Ogaki and Reinhart (1998). The habit parameter $\gamma$ is assumed to be from the Gamma distribution with a mean of 0.7 and a standard deviation of 0.1 . We set the prior mean of the durable investment adjustment cost $\psi$ to 4 with a standard deviation of 1 . The prior distribution for the degree of partial indexation for non-durable firms $l_{c}$ is centered at 0.5 with a standard deviation of 0.15 . We use the Gamma distribution with a mean of 50 and a standard deviation of 20 for the prior distribution for $\phi_{w}$. This prior is the same as the one employed in Gerali, Neri, Sessa, and Signoretti (2010), and when preferences are separable, this prior mean is translated to the Calvo wage parameter and has a value of 0.358 . We assume that the persistence of the aggregate productivity shock is higher than that of durable sector-specific technology shock. The former has a prior mean of 0.7, and the latter is assumed to be 0.5 , with a standard deviation of 0.2 . For the monetary policy coefficients, we adopt the prior distributions used in Del Negro and Schorfheide (2008) and Guerron-Quintana and Nason (2012). The prior distributions for the persistence parameter for the remaining structural shocks are all assumed to be Beta distributions with a mean of 0.5 and a standard deviation of 0.2. We use the Inverse Gamma distribution with a mean of 0.1 and a standard deviation of 2 for the prior distributions for the standard deviations of the structural shocks.

\subsection{Estimation Results}

We estimate four different specifications to determine the role of nominal wage rigidities and non-separable preferences in accounting for the hump-shaped responses to a monetary shock. Table 2 presents the posterior distributions of the model parameters obtained from the random walk Metropolis-Hastings algorithm with 300,000 draws (the first 30,000 draws are discarded as a burn-in period) together with the prior means. We set the scaling parameter such that the average acceptance rate is about $30 \%$. The column labeled 
Table 2: Posterior Distributions

\begin{tabular}{|c|c|c|c|c|c|}
\hline & & & Posterior & Distributions & \\
\hline & Prior Mean & Sticky Non-Separable & Sticky Separable & Flexible Non-Separable & Flexible Separable \\
\hline $1 / \sigma$ & 1.5 & 2.2788 & n.a. & 2.7288 & n.a. \\
\hline & & $(2.0361,2.6052)$ & & $(2.2957,3.1482)$ & \\
\hline$\rho$ & 1.17 & 1.1748 & 1.273 & 1.1072 & 1.201 \\
\hline & & $(1.0305,1.2838)$ & $(1.2210,1.3364)$ & $(0.9619,1.2367)$ & $(1.0708,1.3603)$ \\
\hline$\gamma$ & 0.7 & 0.8111 & 0.8666 & 0.6172 & 0.7503 \\
\hline & & $(0.7945,0.8281)$ & $(0.8611,0.8729)$ & $(0.5613,0.665)$ & $(0.7187,0.7847)$ \\
\hline$\psi$ & 4 & 4.2619 & 4.5726 & 1.6428 & 2.9042 \\
\hline & & $(3.4010,5.0241)$ & $(4.3593,4.7691)$ & $(1.2511,1.9891)$ & $(2.4837,3.4119)$ \\
\hline$l_{c}$ & 0.5 & 0.0545 & 0.0797 & 0.0432 & 0.0472 \\
\hline & & $(0.0275,0.0791)$ & $(0.0609,0.1036)$ & $(0.0186,0.0715)$ & $(0.0202,0.0727)$ \\
\hline$\phi_{w}$ & 50 & 89.2936 & 96.7479 & n.a. & n.a. \\
\hline & & $(86.5537,92.0413)$ & $(95.1163,98.562)$ & & \\
\hline$\rho_{A}$ & 0.7 & 0.9972 & 0.9987 & 0.9973 & 0.9951 \\
\hline & & $(0.9971,0.9974)$ & $(0.9985,0.9988)$ & $(0.9969,0.998)$ & $(0.9912,0.9997)$ \\
\hline$\rho_{A_{x}}$ & 0.5 & 0.9568 & 0.9244 & 0.8436 & 0.7182 \\
\hline & & $(0.9334,0.9897)$ & $(0.8519,0.9859)$ & $(0.7357,0.9957)$ & $(0.5483,0.8420)$ \\
\hline$\rho_{R}$ & 0.5 & 0.7291 & 0.7089 & 0.6124 & 0.5521 \\
\hline & & $(0.7024,0.7515)$ & $(0.7042,0.7134)$ & $(0.5251,0.6979)$ & $(0.4798,0.6300)$ \\
\hline$\rho_{\pi}$ & 2 & 2.2907 & 2.2769 & 2.9443 & 3.0708 \\
\hline & & $(2.2622,2.3218)$ & $(2.2640,2.2932)$ & $(2.6590,3.2525)$ & $(2.6542,3.5579)$ \\
\hline$\rho_{Y}$ & 0.2 & 0.0001 & 0.0001 & 0.0006 & 0.0014 \\
\hline & & $(0,0.0002)$ & $(0,0.0001)$ & $(0,0.0011)$ & $(0.0004,0.0023)$ \\
\hline$\rho_{b}$ & 0.5 & 0.3619 & 0.5168 & 0.7436 & 0.7869 \\
\hline & & $(0.3533,0.3728)$ & $(0.5140,0.5187)$ & $(0.6886,0.8303)$ & $(0.7135,0.853)$ \\
\hline$\rho_{\epsilon_{r}}$ & 0.5 & 0.6369 & 0.6247 & 0.5883 & 0.4472 \\
\hline & & $(0.6333,0.6405)$ & $(0.6225,0.6266)$ & $(0.5666,0.6058)$ & $(0.3695,0.5249)$ \\
\hline$\rho_{\mu_{w}}$ & 0.5 & 0.9574 & 0.9877 & 0.9811 & 0.9893 \\
\hline & & $(0.9565,0.9582)$ & $(0.9876,0.9877)$ & $(0.9795,0.9843)$ & $(0.9860,0.9926)$ \\
\hline$\theta$ & 0.5 & 0.7071 & 0.7096 & 0.1066 & 0.049 \\
\hline & & $(0.7022,0.7121)$ & $(0.7026,0.7161)$ & $(0.0483,0.1543)$ & $(0.0107,0.0893)$ \\
\hline$\rho_{\mu_{c}}$ & 0.5 & 0.966 & 0.962 & 0.9278 & 0.9345 \\
\hline & & $(0.9654,0.9664)$ & $(0.9616,0.9623)$ & $(0.9233,0.9314)$ & $(0.9184,0.9536)$ \\
\hline$\rho_{\mu_{x}}$ & 0.5 & 0.977 & 0.9849 & 0.9757 & 0.981 \\
\hline & & $(0.9762,0.9777)$ & $(0.9848,0.985)$ & $(0.9736,0.9779)$ & $(0.9772,0.9857)$ \\
\hline$\sigma_{\xi}$ & 0.1 & 0.0121 & 0.012 & 0.0119 & 0.012 \\
\hline & & $(0.0118,0.0123)$ & $(0.0118,0.0121)$ & $(0.0118,0.0122)$ & $(0.0118,0.0122)$ \\
\hline$\sigma_{\xi_{x}}$ & 0.1 & 0.0124 & 0.012 & 0.012 & 0.0122 \\
\hline & & $(0.0120,0.0128)$ & $(0.0118,0.0121)$ & $(0.0118,0.0122)$ & $(0.0118,0.0127)$ \\
\hline$\sigma_{\xi_{R}}$ & 0.1 & 0.0119 & 0.0118 & 0.0119 & 0.0119 \\
\hline & & $(0.0118,0.0119)$ & $(0.0118,0.0119)$ & $(0.0118,0.0121)$ & $(0.0118,0.0122)$ \\
\hline$\sigma_{\xi_{b}}$ & 0.1 & 0.0367 & 0.0288 & 0.0217 & 0.0186 \\
\hline & & $(0.0332,0.0409)$ & $(0.0273,0.0303)$ & $(0.0198,0.0238)$ & $(0.0167,0.0203)$ \\
\hline$\sigma_{\xi_{\epsilon_{r}}}$ & 0.1 & 0.0183 & 0.0192 & 0.012 & 0.0121 \\
\hline & & $(0.0156,0.0205)$ & $(0.0179,0.0203)$ & $(0.0118,0.0123)$ & $(0.0118,0.0124)$ \\
\hline$\sigma_{\xi_{\mu w}}$ & 0.1 & 0.0864 & 0.0972 & 0.0184 & 0.0263 \\
\hline & & $(0.0814,0.0920)$ & $(0.0939,0.1006)$ & $(0.0161,0.0209)$ & $(0.0233,0.0294)$ \\
\hline$\sigma_{\xi_{\mu_{c}}}$ & 0.1 & 0.0148 & 0.016 & 0.0172 & 0.0189 \\
\hline & & $(0.0141,0.0154)$ & $(0.0156,0.0166)$ & $(0.0162,0.0184)$ & $(0.0173,0.0203)$ \\
\hline$\sigma_{\xi_{\mu_{x}}}$ & 0.1 & 0.0124 & 0.0122 & 0.0126 & 0.0123 \\
\hline & & $(0.0118,0.0131)$ & $(0.0118,0.0127)$ & $(0.0118,0.0135)$ & $(0.0118,0.0128)$ \\
\hline Log & rginal Density & 4757.04 & 4732.98 & 4628.39 & 4628.29 \\
\hline
\end{tabular}

Note: The numbers reported for the posterior distributions under different specifications are posterior means. The associated $90 \%$ probability intervals are reported in parentheses. The posterior distributions are obtained using the random walk Metropolis-Hastings algorithm with 300,000 draws (the first 30,000 draws are discarded as a burn-in period). We use the modified Harmonic mean estimator of Geweke (1999) to obtain the log marginal density. 
Sticky Non-Separable reports the posterior means and the associated $90 \%$ credible interval for our benchmark specification, where sticky wages and non-separable preferences are incorporated together with the nondurable habit and durable investment adjustment costs.

The posterior mean of $1 / \sigma$ is 2.2788 , and thus, the implied intertemporal elasticity of substitution is 0.44. The associated $90 \%$ probability interval ranges from 2.0361 to 2.6052 . We can see that the separable preferences (i.e., $\sigma \rightarrow 1$ ) are clearly outside the $90 \%$ probability interval. This is in line with Basu and Kimball (2002), Guerron-Quintana (2008), and Kim and Katayama (2013), which support non-separable preferences.

The posterior mean of the elasticity of substitution between non-durable and durable consumption $(\rho)$ is 1.1748, suggesting that they are substitutes. This is in line with the earlier findings of Ogaki and Reinhart (1998), Piazzesi, Schneider, and Tuzel (2007), and Kim and Katayama (2013).

The posterior mean of the habit parameter $(\gamma)$ is 0.8111 with the $90 \%$ credible set ranging from 0.7945 to 0.8281. This estimate appears to be higher than those found in other studies (e.g., Smets and Wouters, 2007; Iacoviello and Neri, 2010).

The posterior mean of the durable investment cost parameter $(\psi)$ under the baseline specification is 4.2619 and the $90 \%$ probability interval ranges from 3.4010 to 5.0241 . This is in line with the estimate of Smets and Wouters (2007). However, it might be the case that the data are not particularly informative about the adjustment cost parameter in this specification.

The posterior distribution of the wage adjustment cost parameter $\left(\phi_{w}\right)$ suggests that there is sizable wage stickiness in the data. The posterior mean of $\phi_{w}$ is 89.2936 with the $90 \%$ probability interval ranging from 86.5537 to 92.0413 . It is possible to translate the wage adjustment cost parameter into the Calvo parameter for wage rigidity when preferences are separable. The posterior mean of $\phi_{w}$ is 96.7479 when preferences are separable. Given the values of $\epsilon_{w}=7.67$ and $\phi_{w}=96.7479$, the implied value of the Calvo parameter for wage rigidity is about 0.47 when preferences are separable.

In our estimation, the posterior distribution of the partial indexation parameter $\left(l_{c}\right)$ for non-durable firms suggest that there is almost no evidence of partial indexation. The posterior mean of $\iota_{c}$ is 0.0545 , with the $90 \%$ credible interval ranging from 0.0275 to 0.0791 . This very weak evidence for partial indexation is similar to the finding in Guerron-Quintana and Nason (2012), who do not find strong support for partial indexation. However, this contrasts with the finding in Iacoviello and Neri (2010), for example.

The posterior means for the monetary policy coefficients are similar to that in earlier studies (e.g., Guerron-Quintana and Nason, 2012). It is notable that the weight on the output gap ( $\left.\rho_{Y}\right)$ is estimated to be 
very small. In fact, the lower bound of the $90 \%$ credible set contains zero. ${ }^{3}$

The posterior distributions suggest that the persistence of the aggregate TFP shock $\left(\rho_{A}\right)$ and that of the durable sector-specific technology shock $\left(\rho_{A_{x}}\right)$ are very high. The posterior mean of $\rho_{A}$ is 0.9972 , and that of $\rho_{A_{x}}$ is 0.9568 . The discount factor and risk premium shocks appear to be less persistent than other shocks. The posterior mean of the persistence parameter of the discount factor shock $\left(\rho_{b}\right)$ is 0.3619 , while that of the risk premium shock $\left(\rho_{\epsilon_{r}}\right)$ is 0.6369 . The non-durable and durable price markup shocks and the wage markup shocks are highly persistent.

The last three columns of Table 2 present the posterior distributions under different specifications. The column labeled Sticky Separable corresponds to the specification where preferences are separable (i.e., $\sigma \rightarrow 1$ ). The column labeled Flexible Non-separable presents the posterior distribution under the assumption that nominal wages are flexible (i.e., $\phi_{w}=0$ ). The column labeled Flexible Separable represents the setting where $\sigma \rightarrow 1$ and $\phi_{w}=0$. Overall, the patterns in the posterior means are similar under the different specifications. However, it is worth emphasizing some differences and similarities.

First, the habit parameter is estimated to be lower with non-separable preferences. With nominal wage rigidity, the posterior mean of $\gamma$ is 0.8111 and 0.8666 with non-separable and separable preferences, respectively. Without nominal wage rigidity, this $\gamma$ is estimated to be 0.6172 with non-separable preferences and 0.7503 with separable preferences. In this case, the $90 \%$ probability intervals do not overlap at all. This pattern is consistent with the finding of Guerron-Quintana (2008), who reports that non-separable preferences reduce the habit persistence parameter in a standard one-sector New Keynesian model using a minimum distance estimator. In addition, the introduction of nominal wage rigidity increases the posterior mean of the habit persistence parameter, irrespective of preferences. When sticky wages are introduced in the estimation, the posterior mean of $\gamma$ increases from 0.6172 to 0.8111 for non-separable preferences and from 0.7503 to 0.8666 for separable preferences.

Second, when non-separability is turned off, the posterior mean of $\phi_{w}$ increases from 89.2936 to 96.7479. This difference seems to be significant. In fact, the $90 \%$ probability intervals under Sticky Non-separable and Sticky Separable do not overlap. Similarly, when wage stickiness is shut down, the posterior mean of $1 / \sigma$ changes from 2.2788 to 2.7288 . In the case of $1 / \sigma$, the $90 \%$ probability intervals are somewhat wider and are somewhat overlapping. As discussed in Kim and Katayama (2013), wage stickiness and non-separability are two important elements in terms of comovement between non-durable and durable spending. If one is

\footnotetext{
${ }^{3}$ In our earlier experiments, we noticed that this coefficient tended to move to the negative region if we used different priors. We conjecture that this occurred because our output gap, which amounts to a linear combination of non-durable and durable expenditures, is not exactly the same as the output gap considered by the monetary authority.
} 
turned off, in some sense, the other has to work more in order to account for the comovement in the data. This suggests that it is important to include both sticky wages and non-separable preferences.

Third, under flexible wages, the adjustment cost parameter for durable investment $(\psi)$ becomes smaller than the one under sticky wages. As with the habit persistent parameter, a similar pattern emerges for the investment adjustment cost parameter. Non-separable preferences result in a lower value of the posterior mean of $\psi$. Guerron-Quintana (2008) reports a similar pattern: in the presence of habits, non-separable preferences result in a lower estimate for the investment adjustment cost parameter.

Fourth, the persistence of the durable-specific technology shock, the risk premium shock, and the MA parameter of the wage markup shock become smaller when wage stickiness is turned off, and the persistence of the discount factor shock becomes much higher.

Lastly, the posterior means of the partial indexation parameter remain very close to zero regardless of the specifications. This is similar to the finding of Guerron-Quintana and Nason (2012). Likewise, the monetary policy coefficient on the output gap $\left(\rho_{Y}\right)$ stays near zero. When we have flexible wages and separable preferences, the lower bound of the $90 \%$ probability interval does not contain zero. The estimate of $\rho_{Y}$ might be affected by different specifications in preferences or wage stickiness.

By comparing the log marginal densities, we can conclude that our baseline specification with sticky wages and non-separable preferences is decisively supported by the data. The data decisively support sticky wages regardless of the preference specifications among different specifications. The difference between non-separable and separable preferences under flexible wages is almost undistinguishable. However, once sticky wages are introduced, it appears that non-separable preferences become more important. This suggests that there is synergy between wage stickiness and non-separable preferences.

To illustrate the dynamic behavior of the model under our baseline specification (i.e., sticky wages plus non-separable preferences), Figure 1 shows the impulse responses to a one-standard-deviation contractionary monetary shock. ${ }^{4}$ Several things are worth mentioning here. First, even though our model is built on Barsky, House, and Kimball (2007), where the comovement puzzle arises, non-separable preferences and sticky wages jointly resolve the comovement problem, as discussed in Kim and Katayama (2013). Second, our estimated model exhibits a pronounced delay in the peak response of non-durable and durable production to the monetary shock. We will return to this issue in Section 3.4. Third, we cannot observe the hump-shaped dynamics in non-durable inflation, because the estimated degree of partial indexation

\footnotetext{
${ }^{4}$ Since our interest is in the delayed effect of monetary shocks, we focus on the impulse response functions for the estimated monetary shock. For the sake of completeness, however, Figure 3 in the Appendix presents the posterior responses of the model variables to other shocks.
} 

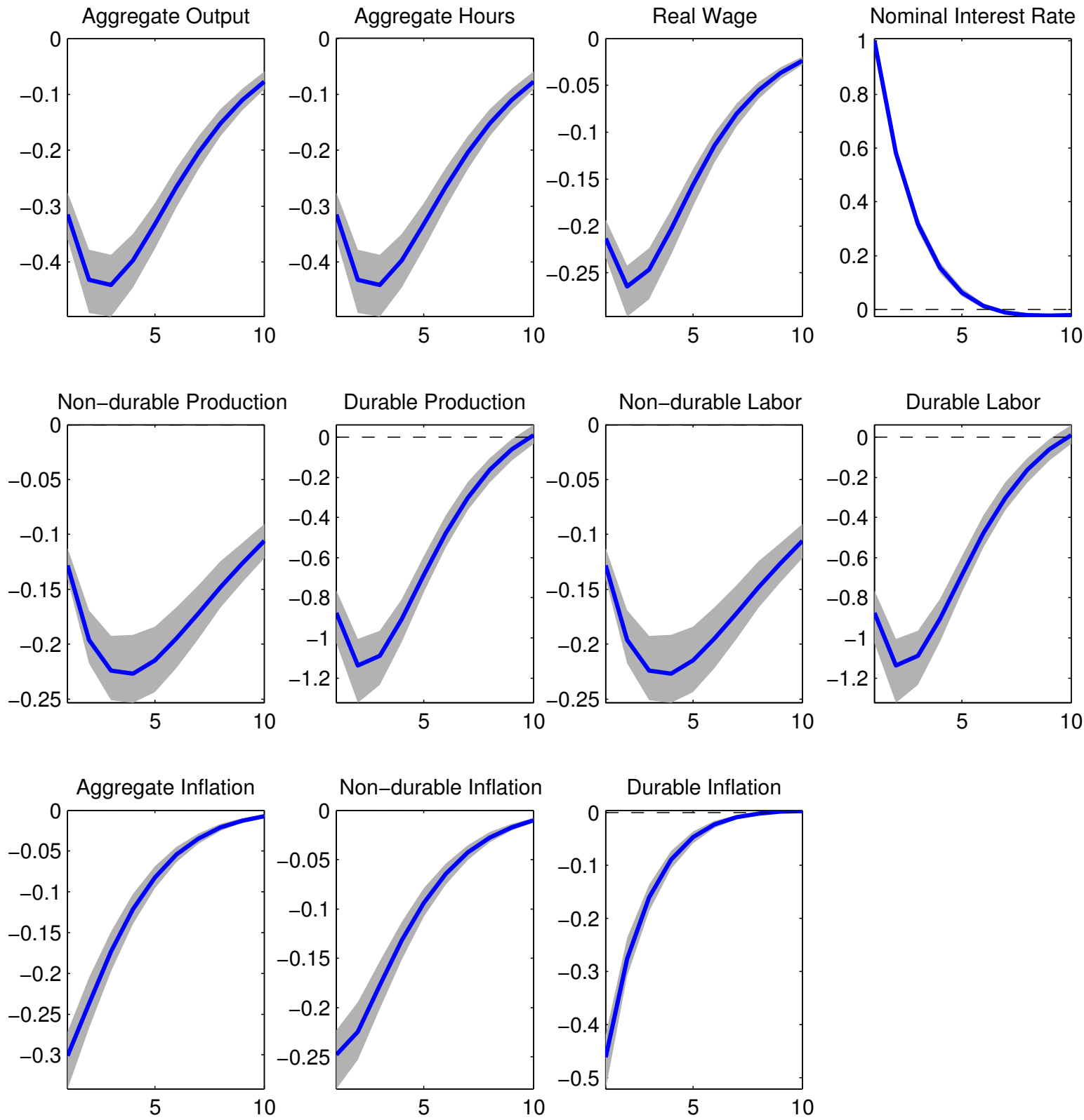

Figure 1: Impulse Responses to a Monetary Shock in the Baseline Specification

Note: The horizontal axes indicate the number of quarters after the shock, and the vertical axes measure percentage deviations from the steady state. The above figures depict the responses of the economy to the one standard-deviation shocks. The solid lines represent the posterior mean responses, and the shaded areas correspond to the $5 \%$ and $95 \%$ posterior intervals.

is very small. As a result, the aggregate inflation rate shows monotonic responses to the monetary shock. Even though the partial indexation is supposed to help generate the hump-shaped response of inflation, the data do not support this mechanism in our setup. Thus, this suggests that we may need an alternative 
Table 3: Posterior Second Moments

\begin{tabular}{cccccc}
\hline & Data & $\begin{array}{c}\text { Sticky } \\
\text { Non-Separable }\end{array}$ & Sticky Separable & $\begin{array}{c}\text { Flexible } \\
\text { Non-Separable }\end{array}$ & $\begin{array}{c}\text { Flexible } \\
\text { Separable }\end{array}$ \\
\hline Standard Deviation & & & & \\
d $c_{t}$ & 0.0057 & 0.0047 & 0.0043 & 0.0057 & 0.0053 \\
$d x_{t}$ & 0.0170 & 0.0216 & 0.0219 & 0.0201 & 0.0226 \\
$\pi_{c, t}$ & 0.0081 & 0.0052 & 0.0052 & 0.0046 & 0.0043 \\
$\pi_{x, t}$ & 0.0065 & 0.0144 & 0.0140 & 0.0178 & 0.0180 \\
$h_{t}$ & 0.0778 & 0.0408 & 0.0614 & 0.0445 & 0.0579 \\
$d w_{t}$ & 0.0060 & 0.0066 & 0.0071 & 0.0138 & 0.0154 \\
$f f_{t}$ & 0.0085 & 0.0102 & 0.0103 & 0.0094 & 0.0091 \\
\hline Autocorrelation & & & & & \\
$d c_{t}$ & 0.4999 & 0.5887 & 0.6003 & 0.6098 & 0.6178 \\
$d x_{t}$ & 0.3037 & 0.5758 & 0.6194 & 0.4579 & 0.6317 \\
$\pi_{c, t}$ & 0.7873 & 0.6409 & 0.6310 & 0.4877 & 0.4783 \\
$\pi_{x, t}$ & 0.8834 & 0.0474 & 0.0429 & -0.1014 & -0.1066 \\
$h_{t}$ & 0.9896 & 0.9170 & 0.9291 & 0.9239 & 0.9302 \\
$d w_{t}$ & 0.0615 & 0.4458 & 0.4510 & -0.0603 & -0.0826 \\
$f f_{t}$ & 0.9528 & 0.6528 & 0.6476 & 0.5894 & 0.5590 \\
\hline
\end{tabular}

Note: The top panel presents posterior standard deviations and the bottom panel shows posterior autocorrelations. The first column contains the standard deviations and autocorrelations of the observable variables. The second to fifth columns report the posterior standard deviations and autocorrelations of variables with the models under different specifications.

explanation for the sluggish response of inflation.

To illustrate the nature of different specifications, Table 3 presents the posterior second moments under different specifications. The top panel of Table 3 compares the standard deviations in the data with those in the estimated models. In general, these estimated models do a reasonably good job of accounting for the observed volatility in the data. However, there are some problems. These models imply too much volatility in the durable inflation rate. Such a tendency is more pronounced if we have flexible wages. In addition, non-separable preferences tend to reduce the volatility of hours. This results in too smooth hours worked compared with the data. This is due to the complementarity between hours and consumption with habit.

The bottom panel of Table 3 summarizes the autocorrelations in the data and in the estimated models. In general, the estimated models have reasonable performance in terms of autocorrelations compared with the data. There are, however, certain dimensions that these models fail to replicate. These models cannot generate the significant persistence in durable price inflation that we observe in the data. While introducing sticky wages helps increase the persistence of non-durable price inflation and the interest rate, it induces too much persistence in durable spending growth and real wage growth.

This may be a slightly disappointing result in the sense that we need non-separable preferences and sticky wages in order to generate the empirically realistic hump-shaped response in non-durable and durable 
Table 4: Posterior Variance Decomposition (\%)

\begin{tabular}{|c|c|c|c|c|c|c|c|c|}
\hline & $\begin{array}{c}\text { Aggregate } \\
\text { TFP }\end{array}$ & $\begin{array}{c}\text { Durable- } \\
\text { Specific } \\
\text { TFP }\end{array}$ & $\begin{array}{c}\text { Monetary } \\
\text { Shock }\end{array}$ & $\begin{array}{c}\text { Discount } \\
\text { Factor } \\
\text { Shock }\end{array}$ & $\begin{array}{c}\text { Risk } \\
\text { Premium } \\
\text { Shock }\end{array}$ & $\begin{array}{l}\text { Wage } \\
\text { Markup } \\
\text { Shock }\end{array}$ & $\begin{array}{c}\text { Non- } \\
\text { durable } \\
\text { Price } \\
\text { Markup } \\
\text { Shock }\end{array}$ & $\begin{array}{c}\text { Durable } \\
\text { Price } \\
\text { Markup } \\
\text { Shock }\end{array}$ \\
\hline \multicolumn{9}{|c|}{ (a) Sticky Non-Separable } \\
\hline$d c_{t}$ & 25.29 & 0.47 & 5.40 & 28.01 & 7.11 & 16.82 & 16.41 & 0.48 \\
\hline$d x_{t}$ & 25.74 & 12.30 & 10.60 & 1.25 & 14.97 & 24.27 & 4.30 & 6.58 \\
\hline$\pi_{c, t}$ & 17.09 & 0.34 & 24.58 & 1.00 & 21.77 & 8.83 & 25.65 & 0.74 \\
\hline$\pi_{x, t}$ & 21.68 & 31.98 & 5.96 & 0.55 & 6.37 & 5.67 & 1.55 & 26.24 \\
\hline$h_{t}$ & 5.67 & 2.82 & 2.43 & 0.30 & 2.69 & 66.44 & 12.85 & 6.80 \\
\hline$d w_{t}$ & 33.30 & 0.00 & 4.94 & 1.14 & 7.24 & 13.93 & 39.42 & 0.03 \\
\hline$f f_{t}$ & 10.35 & 3.11 & 55.45 & 0.63 & 16.21 & 5.78 & 5.87 & 2.59 \\
\hline \multicolumn{9}{|c|}{ (b) Sticky Separable } \\
\hline$d c_{t}$ & 21.95 & 1.76 & 2.35 & 33.44 & 3.87 & 16.45 & 17.15 & 3.02 \\
\hline$d x_{t}$ & 23.80 & 15.33 & 6.60 & 2.91 & 11.30 & 25.62 & 3.29 & 11.15 \\
\hline$\pi_{c, t}$ & 17.20 & 0.05 & 19.60 & 3.01 & 21.35 & 8.05 & 30.58 & 0.14 \\
\hline$\pi_{x, t}$ & 21.38 & 28.94 & 5.24 & 1.37 & 7.01 & 5.20 & 2.42 & 28.44 \\
\hline$h_{t}$ & 2.06 & 2.25 & 0.59 & 0.12 & 0.79 & 87.08 & 2.27 & 4.83 \\
\hline$d w_{t}$ & 29.20 & 0.00 & 4.30 & 2.01 & 7.66 & 10.99 & 45.81 & 0.02 \\
\hline$f f_{t}$ & 10.35 & 2.85 & 55.22 & 2.00 & 15.43 & 5.56 & 6.11 & 2.48 \\
\hline \multicolumn{9}{|c|}{ (c) Flexible Non-Separable } \\
\hline$d c_{t}$ & 30.73 & 0.40 & 3.27 & 10.33 & 3.76 & 23.72 & 27.13 & 0.66 \\
\hline$d x_{t}$ & 25.62 & 21.23 & 0.19 & 15.94 & 0.23 & 24.94 & 1.57 & 10.29 \\
\hline$\pi_{c, t}$ & 5.73 & 0.29 & 27.16 & 4.65 & 35.46 & 6.09 & 19.12 & 1.51 \\
\hline$\pi_{x, t}$ & 5.45 & 19.05 & 21.14 & 3.24 & 22.89 & 9.02 & 6.84 & 12.38 \\
\hline$h_{t}$ & 3.88 & 0.80 & 0.10 & 0.42 & 0.13 & 82.65 & 7.76 & 4.26 \\
\hline$d w_{t}$ & 12.75 & 0.34 & 24.05 & 3.53 & 25.07 & 11.41 & 21.92 & 0.93 \\
\hline$f f_{t}$ & 8.25 & 7.20 & 13.14 & 6.20 & 46.56 & 9.03 & 4.97 & 4.65 \\
\hline \multicolumn{9}{|c|}{ (d) Flexible Separable } \\
\hline$d c_{t}$ & 23.47 & 0.66 & 1.35 & 21.35 & 1.14 & 21.80 & 25.66 & 4.57 \\
\hline$d x_{t}$ & 19.30 & 9.18 & 0.04 & 24.33 & 0.03 & 25.99 & 4.00 & 17.13 \\
\hline$\pi_{c, t}$ & 5.36 & 0.66 & 32.29 & 15.32 & 22.37 & 7.74 & 14.91 & 1.35 \\
\hline$\pi_{x, t}$ & 2.58 & 13.76 & 25.27 & 5.78 & 25.70 & 4.63 & 11.20 & 11.09 \\
\hline$h_{t}$ & 2.67 & 0.31 & 0.01 & 0.58 & 0.01 & 89.61 & 1.27 & 5.55 \\
\hline$d w_{t}$ & 13.22 & 0.98 & 24.49 & 4.79 & 26.28 & 4.39 & 24.13 & 1.72 \\
\hline$f f_{t}$ & 7.75 & 6.87 & 8.60 & 22.39 & 35.61 & 11.37 & 2.85 & 4.56 \\
\hline
\end{tabular}

Note: The numbers reported here are the percentages of variance of each variable explained by the structural shocks in the model under different specifications.

spending. However, sticky wages bring undesirably strong persistence, especially in real wage growth. This suggests that we need an alternative mechanism to obtain a delayed response from non-durable and durable spending instead of relying on sticky wages.

Table 4 summarizes the posterior variance decomposition results under different specifications. For our baseline specification, the aggregate TFP shock, monetary shock, wage markup shock, and non-durable 
price markup shock play important roles in explaining variations in the data. However, the importance of the durable-specific TFP shock, risk premium shock, and durable price markup shock are somewhat limited.

There are not many differences in the variance decomposition results between non-separable and separable preferences. When there are sticky wages, the only significant difference is that the role of the wage markup shock in explaining variations in log hours becomes more important once preferences are separable. When wages are flexible, the difference in preferences affects the role of the discount factor shock and the risk premium shock.

The difference in wage stickiness changes the nature of the variance decomposition. Once wages become flexible, the importance of the aggregate TFP shock and the monetary policy shock becomes smaller, and the risk premium shock and wage markup shock play more important roles in explaining variations in the data.

\subsection{Inspecting the Source of the Hump-shaped Response}

This section illustrates the role played by the features of our two-sector New Keynesian model with flexibly priced durable goods (i.e., habit formation, investment adjustment costs, sticky wages, and non-separable preferences) in generating the hump-shaped responses of non-durable and durable spending to a monetary shock. Figure 2 presents the impulse response functions to a one-unit contractionary monetary shock under the four different specifications of our model. Each impulse response function is drawn using the posterior means of the parameters presented in Table 2.

\subsubsection{The model with only habit formation and adjustment costs}

It is instructive to consider the version of our model that only features habit formation and investment adjustment costs first. The solid gray line labeled "Flexible Separable" in Figure 2 plots the responses of this model to a one-unit contractionary monetary shock.

Interestingly, while non-durable consumption exhibits an inverted hump-shaped response, its peak response is delayed by only one quarter after the shock. In contrast, empirical studies typically find sluggish responses of non-durable spending and its maximal response arises several quarters after the monetary shock in identified VAR models (see, e.g., Monacelli, 2009).

In this case, the response of durable spending is even more problematic. Durable spending shows the "wrong" kind of hump-shaped response to the contractionary monetary shock: it gradually increases 

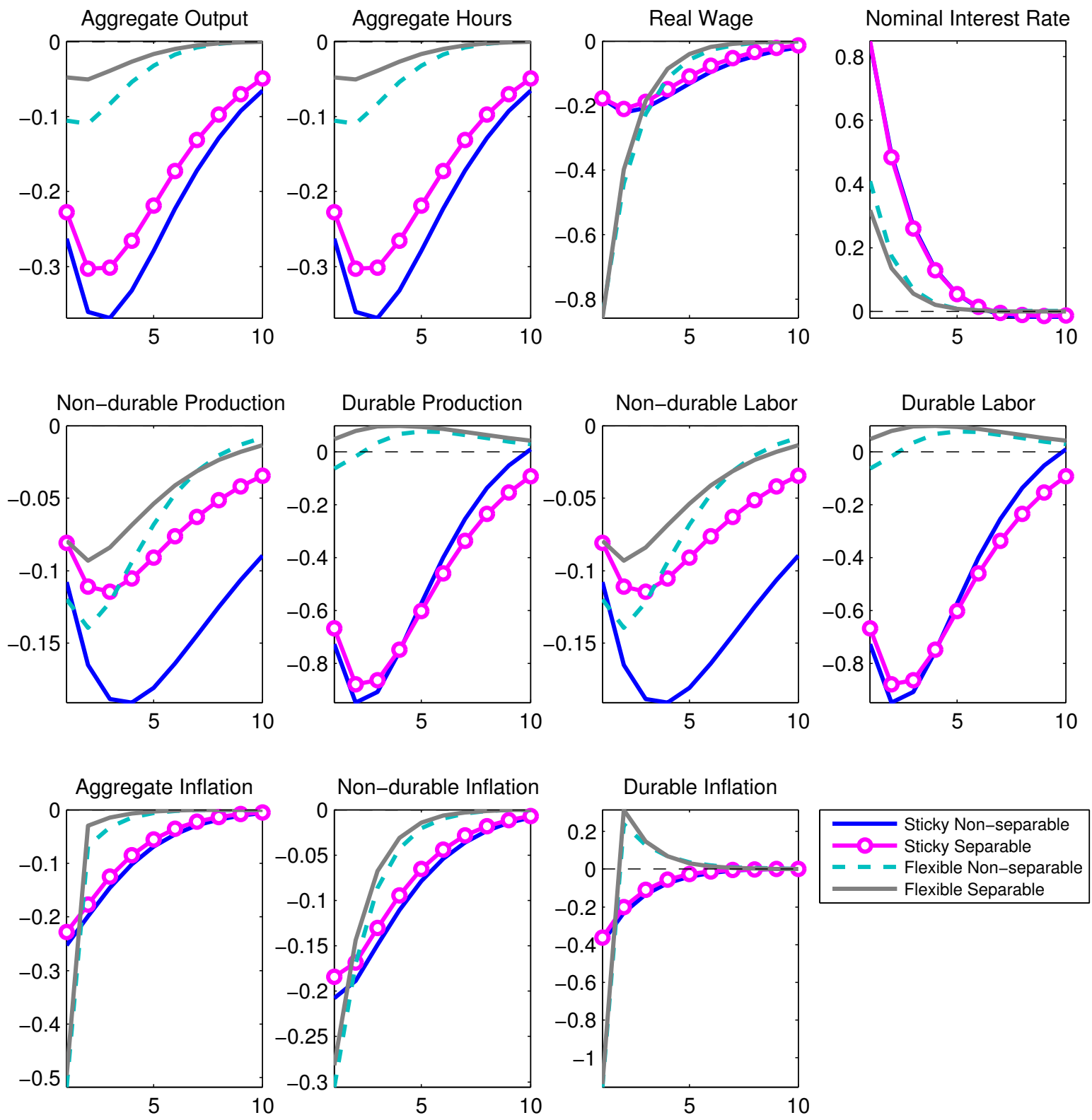

Figure 2: Comparison of IRFs to a One-unit Monetary Shock

Note: The horizontal axes indicate the number of quarters after the shock, and the vertical axes measure percentage deviations from the steady state. The above figures depict the responses of the economy to the one-unit contractionary monetary shock.

after the monetary contraction. This perverse response of durable spending is related to the comovement problem raised by Barsky, House, and Kimball (2007). When non-durable goods prices are sticky and durable goods prices are flexible, the relative price of durable goods decreases after the contractionary monetary shock. As Barsky, House, and Kimball (2007) emphasize, the shadow values of the durable goods 
are almost unaffected by the monetary contraction, and therefore, households do not have to care about smoothing out purchases of durable goods when the relative price of durable goods temporarily decreases. Hence, the temporary drop in the relative price of durable goods causes a large shift to durable goods spending. Certainly, durable investment adjustment costs serve to moderate this intertemporal substitution effect, and thus, they generate the counterfactual hump-shaped increase in durable spending.

In a two-sector sticky price model with flexibly priced durable goods, therefore, habit formation and investment adjustment costs are not sufficient to successfully match the delayed responses of non-durable and durable spending documented in the identified VAR studies.

\subsubsection{Adding non-separability}

We now examine the consequences of incorporating non-separable preferences together with habit formation and investment adjustment costs in the estimation. The dashed line labeled "Flexible Non-Separable" in Figure 2 depicts the responses of the model to the monetary shock under this specification.

Several noticeable differences emerge because of non-separable preferences. First, as we mentioned, the estimated habit persistence parameter declined from 0.7503 to 0.6172 with non-separable preferences (Table 2). Even with lower habit persistence, the model is still capable of generating a one quarter delay in the peak response of non-durable spending. To understand the difference induced by non-separable preferences, we note that non-separability implies complementarity between consumption and labor. With this interaction between consumption and labor, the growth of the marginal utility of non-durable consumption depends not only on the growth rate of non-durable consumption, but also on the growth rate of the labor supply. Thus, as Guerron-Quintana (2008) demonstrates, the complementarity dampens the dependence of the growth rate of non-durable consumption on the real interest rate. This implies that a hump-shaped non-durable spending response becomes more compatible with the higher real interest rate induced by the contractionary monetary shock, even with a lower degree of habit formation. Put differently, despite a lower degree of habit persistence, non-separable preferences serve to generate a more pronounced inverted hump-shaped non-durable consumption response to the contractionary monetary shock, which can be seen in Figure 2.

Second, durable spending decreases on impact after the contractionary monetary shock, and hence, the comovement problem becomes less severe. As we have shown in our previous paper (Kim and Katayama, 2013), the complementarity between consumption and labor mitigates the reduction in the relative price of durable goods after the monetary contraction. If the complementarity is strong enough, durable spending 
might decrease. In this case, non-separable preferences resolve the comovement problem, at least for the impact period. ${ }^{5}$

\subsubsection{Adding sticky wages}

The inclusion of sticky wages also significantly changes the estimated responses of the model to the monetary shock. The solid line with markers in Figure 2 labeled "Sticky Separable" shows the estimated responses when nominal wage rigidity is additionally included with habit formation and adjustment costs with separable preferences. Most notably, when investment adjustment costs meet sticky wages, durable spending now exhibits an inverted hump-shaped response to the contractionary monetary shock in the two-sector New Keynesian model with flexibly priced durable goods. Compared to the previous two cases, sticky wages substantially mitigate the drop in the relative price of durable goods, which enables durable spending to decrease. Because of investment adjustment costs, durable spending gradually decreases rather than undergoing an immediate reduction on the impact period. Therefore, investment adjustment costs need sticky wages in order to produce an inverted hump-shaped durable spending response to the monetary shock in the two-sector New Keynesian model.

To some extent, sticky wages also improve the dynamic behavior of non-durable consumption. Its peak response is delayed one more quarter, and it becomes more persistent compared to the previous two cases. However, this improvement might be due to the fact that the habit persistence is estimated to be much higher with sticky wages. As shown in Table 2, the posterior mean of habit persistence is 0.8666 when sticky wages are estimated together with habit formation and durable investment adjustment costs. This value is much larger than the ones obtained in the previous cases (0.7503 and 0.6172, respectively). Despite a high degree of habit persistence, the fact that non-durable spending does not demonstrate a significant delay in its peak response implies that habit formation and sticky wages are not sufficient for the two-sector New Keynesian model to match the dynamics of non-durable consumption to a monetary shock.

\subsubsection{Adding non-separability and sticky wages together}

Finally, the solid blue (dark) line in Figure 2 depicts the responses of the model to the contractionary shock when both non-separable preferences and sticky wages are included together with habit formation and investment adjustment costs. Combining non-separable preferences and sticky wages significantly

\footnotetext{
${ }^{5}$ Note that our specification here is different from the one in Kim and Katayama (2013), which does not have habit formation and durable investment adjustment costs. Kim and Katayama (2013) include variable capital utilization to help resolve the comovement problem; this is absent here.
} 
improves the model's ability to match the dynamic response of non-durable spending reported in the VAR studies: nondurable consumption now reaches its maximal response three quarters after the monetary shock. More interestingly, when sticky wages meet non-separable preferences, an even lower degree of habit persistence yields additional delay in the peak response compared to the case where sticky wages alone are introduced. As shown in Table 2, the posterior mean of the habit persistence parameter decreases from 0.8666 to 0.8111 by introducing non-separable preferences to sticky wages.

It is straightforward to understand why introducing sticky wages and non-separable preferences, which are mutually reinforcing, together generates a significant inverted hump-shaped non-durable consumption response. When sticky wages induce a more sluggish labor response, the complementarity between consumption and labor implied by non-separable preferences leads to a further delay in the peak response of non-durable spending, even with a lower degree of habit persistence. In addition to habit formation, therefore, non-separable preferences and sticky wages should be considered important factors for generating a significant inverted hump-shaped response of non-durable spending to a monetary shock in the two-sector New Keynesian model.

The introduction of non-separable preferences to sticky wages does not significantly change the dynamic behavior of durable spending. Compared to the case where sticky wages alone are considered, adding nonseparable preferences to sticky wages yields a slightly larger response of durable spending, but it does not alter the general shape of the response. However, this does not imply that non-separable preferences are irrelevant to the response of durable spending when nominal wages are sticky. Even though the introduction of non-separable preferences to sticky wages lowers the posterior mean of the adjustment parameter $(\psi)$ from 4.5726 to 4.2619 , as shown in Table 2, durable spending demonstrates a similar response. This result is related to the fact that non-separable preferences yield a lower posterior mean of habit persistence. As Guerron-Quintana (2008) explains, a low value of habit persistence gives households more flexibility to adjust consumption, which, in turn, implies less pressure on the initial response of durable spending following a monetary expansion. Consequently, a smaller adjustment cost is required to mimic similar durable spending dynamics.

\section{Conclusion}

This paper investigated the nature of the gradual response of the economy to monetary shocks. In particular, we took the simple two-sector New Keynesian model of Barsky, House, and Kimball (2007) with sticky 
non-durable prices and flexible durable goods prices. We extended it by incorporating habit formation in nondurable goods, adjustment costs for durable goods purchases, sticky wages, and non-separable preferences between consumption and leisure to account for the pronounced hump-shaped responses of non-durable and durable spending observed in empirical VAR studies. We employed a Bayesian approach to determine the factors that are quantitatively important in generating the hump-shaped responses to monetary shocks.

We find that habit formation and investment adjustment costs, which are considered typical factors for generating the hump-shaped responses of nondurable and durable spending to monetary shocks, do not successfully produce the significant hump-shaped responses in the two-sector New Keynesian model with flexibly priced durable goods. The main reason is that non-durable consumption habit and durable investment adjustment costs cannot resolve the comovement problem that arises in the two-sector New Keynesian model. To increase the pronounced delayed responses of non-durable and durable spending in the two-sector New Keynesian model, non-separable preferences and sticky wages should be incorporated into the model with habit formation and durable investment adjustment costs. Once we include both nonseparable preferences and sticky wages, they complement the non-durable consumption habit and durable investment adjustment costs and produce more realistic responses from non-durable and durable spending. Furthermore, the data decisively support both non-separable preferences and sticky wages.

There are several things that our model cannot explain and are thus left for our future research. First, in our setup, we cannot find strong support for the price indexation. As a result, we cannot account for the hump-shaped response of inflation to a monetary shock. Second, even though sticky wages are important for the dynamic responses of model variables, wage stickiness has an unfavorable effect on the autocorrelation property of real wage growth in the data. That is, the real wage growth has too much persistence if we include sticky wages. These two issues suggest that we need alternative mechanisms that can be supported by the data. 


\section{Appendix}

\section{Impulse Response Functions}
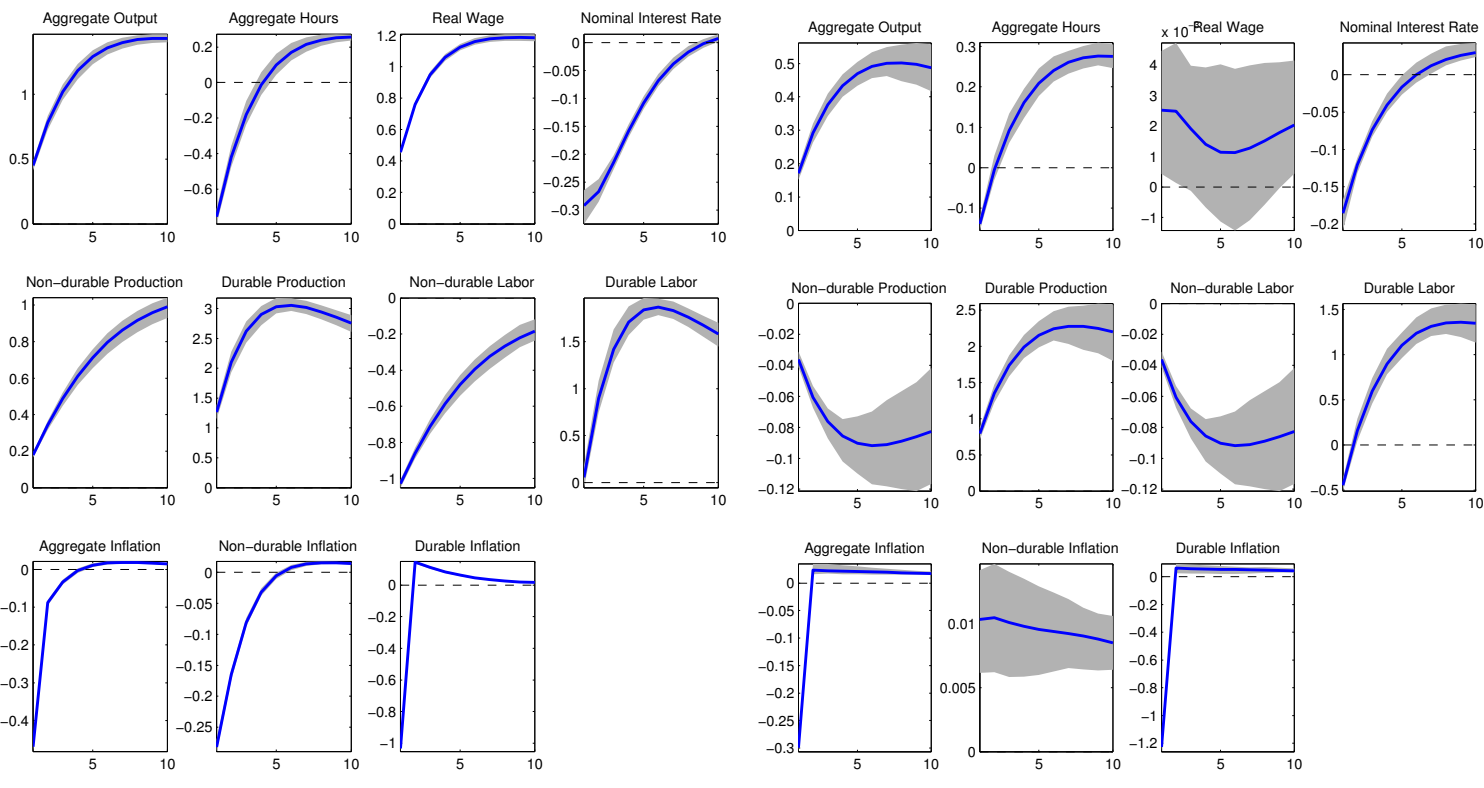

(a) Aggregate TFP Shock

(b) Durable-Specific TFP Shock
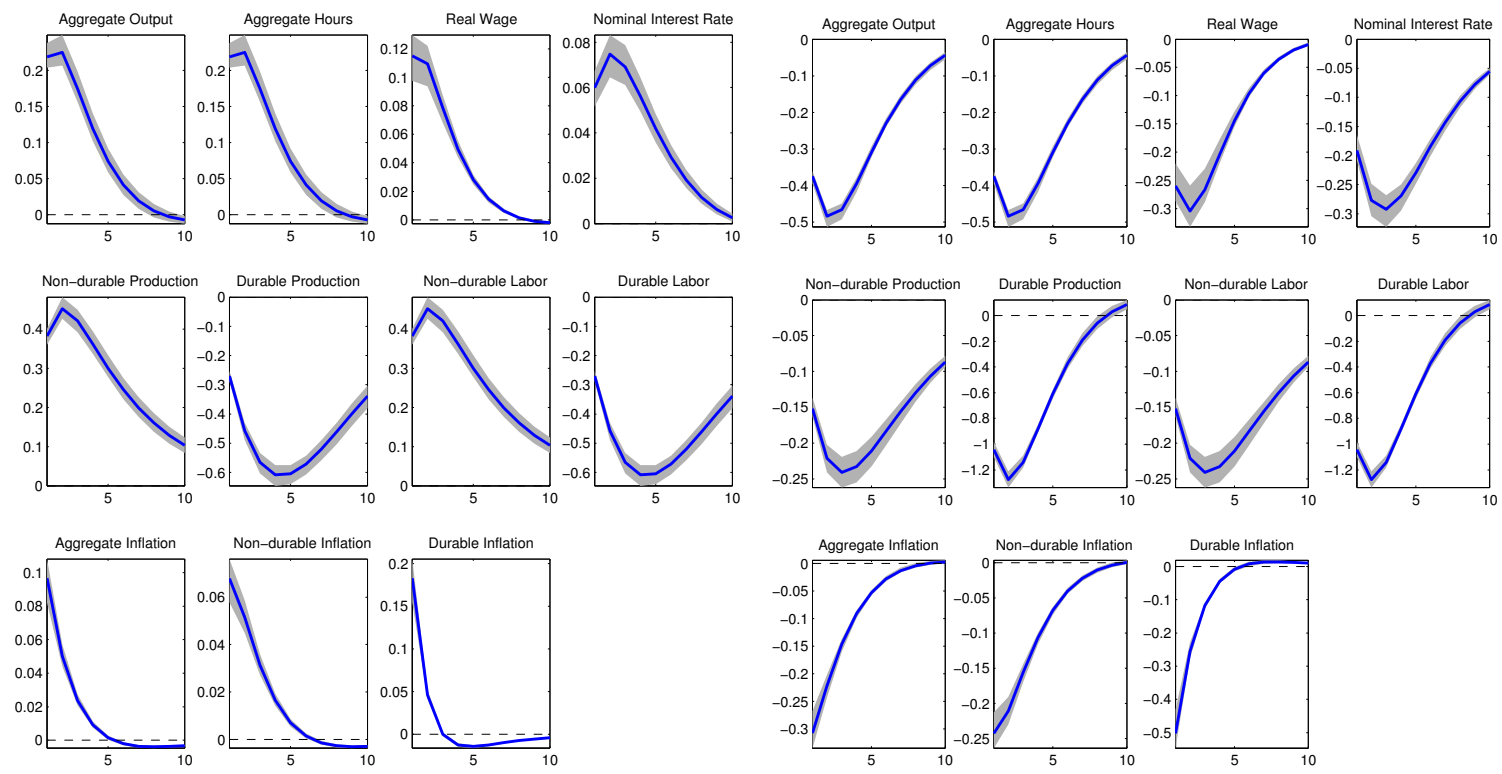

(c) Discount Factor Shock

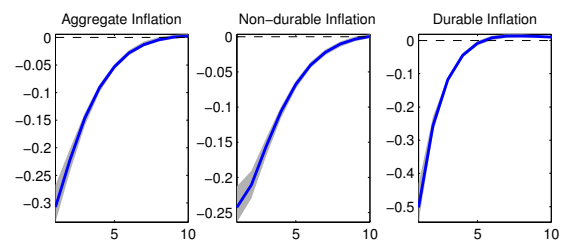

(d) Risk Premium Shock

Figure 3: Impulse Response Functions in the Baseline Specification

Note: The horizontal axes indicate the number of quarters after the shock and the vertical axes measure percentage deviations from the steady state. The above figures depict the responses of the economy to the one standard-deviation shocks. The solid lines represent the posterior mean responses, and the shaded areas correspond to the $5 \%$ and $95 \%$ posterior intervals. 

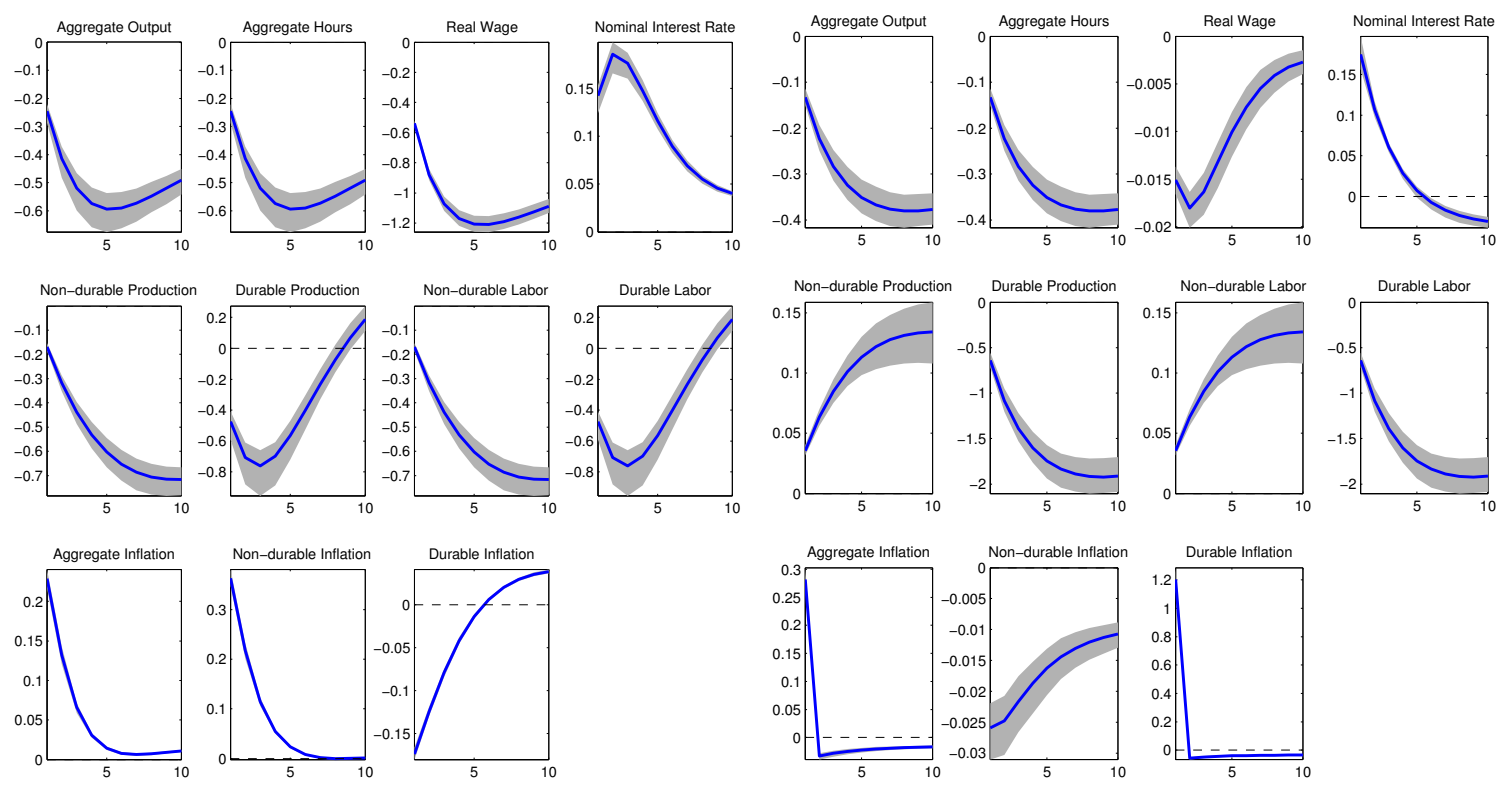

(e) Nondurable Price Markup Shock

(f) Durable Price Markup Shock
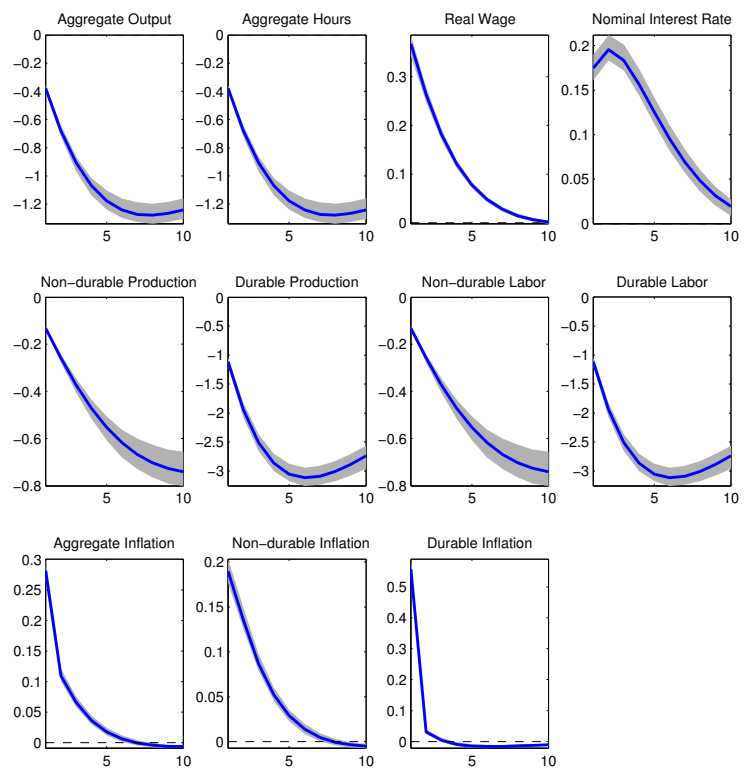

(g) Wage Markup Shock

Figure 3: Impulse Response Functions in the Baseline Specification (Cont.) 


\section{References}

Abel, A., and O. Blanchard (1983): “An Intertemporal Equilibrium Model of Saving and Investment," Econometrica, 51(3), 675-692.

Barsky, R., C. House, and M. Kimball (2003): “Do Flexible Durable Goods Prices Undermine Sticky Price Models?," NBER working papers: No. 9823.

_ (2007): "Sticky-Price Models and Durable Goods," American Economic Review, 97(3), 984-998.

Basu, S., and M. S. Kimball (2002): “Long-Run Labor Supply and the Elasticity of Intertemporal Substitution for Consumption," Working Paper, University of Michigan.

Calvo, G. (1983): "Staggered Prices in a Utility Maximizing Framework," Journal of Monetary Economics, 12(3), 383-398.

Carlstrom, C. T., and T. S. Fuerst (2010): “Nominal Rigidities, Residential Investment, and Adjustment Costs," Macroeconomic Dynamics, 14, 136-148.

Christiano, L., M. Eichenbaum, and C. Evans (1996): Identification and the Effects of Monetary Policy Shocks. In Mario Blejer and Evi Eckstein and Leonardo Leiderman eds., Finanicial Factors in Economics Stabilization and Growth, Cambridge University Press.

(2005): "Nominal Rigidities and the Dynamic Effects of a Shock to Monetary Policy," Journal of Political Economy, 113(1), 1-45.

Del Negro, M., and F. Schorfheide (2008): “Forming Priors for DSGE Models (and How It Affects the Assessment of Nominal Rigidities)," Journal of Monetary Economics, 55(7), 1191-1208.

Erceg, C., and A. Levin (2006): “Optimal Monetary Policy with Durable Consumption Goods," Journal of Monetary Economics, 53(7), 1341-1359.

Erceg, C. J., D. W. Henderson, and A. T. Levin (2000): “Optimal Monetary Policy with Staggered Wage and Price Contracts," Journal of Monetary Economics, 46(2), 281-313.

Funrer, J. C. (2000): “Habit Formation in Consumption and Its Implications for Monetary-Policy Models," American Economic Review, 90(3), 367-390. 
Gerali, A., S. Neri, L. Sessa, and F. M. Signoretti (2010): “Credit and Banking in a DSGE Model of the Euro Area," Journal of Money, Credit and Banking, 42, 107-141.

GeweKe, J. (1999): “Using Simulation Methods for Bayesian Econometric Models: Inference, Development, and Communication," Econometric Reviews, 18(1), 1-73.

Guerron-Quintana, P., and J. M. Nason (2012): “Bayesian Estimation of DSGE Models,” Working Paper 12-4, FRB of Philadelphia.

Guerron-Quintana, P. A. (2008): “Refinements on Macroeconomic Modeling: The Role of Non-Separability and Heterogeneous Labor Supply," Journal of Economic Dynamics and Control, 32(11), 3613-3640.

Hayashi, F. (1982): “Tobin's Marginal q and Average q: A Neoclassical Interpretation," Econometrica, 50(1), 213-224.

IACoviello, M., AND S. Neri (2010): “Housing Market Spillovers: Evidence from an Estimated DSGE Model," American Economic Journal: Macroeconomics, 2, 125-64.

KIM, J. (2000): “Constructing and Estimating a Realistic Optimizing Model of Monetary Policy," Journal of Monetary Economics, 45(2), 329-359.

Kim, K. H., and M. Katayama (2013): "Non-Separability and Sectoral Comovement in a Sticky Price Model," Journal of Economic Dynamics and Control, Forthcoming.

Leeper, E., C. Sims, and T. Zha (1996): “What Does Monetary Policy Do?," Brookings Papers on Economic Activity, (2), 1-63.

LucAs, R., And E. Prescott (1971): “Investment Under Uncertainty,” Econometrica, 39(5), 659-681.

Monacelli, T. (2009): “New Keynesian Models, Durable Goods, and Collateral Constraints," Journal of Monetary Economics, 56(2), 242-254.

Ogaki, M., and C. M. Reinhart (1998): “Measuring Intertemporal Substitution: The Role of Durable Goods,” Journal of Political Economy, 106(5), 1078-1098.

Piazzesi, M., M. Schneider, and S. Tuzel (2007): “Housing, Consumption, and Asset Pricing,” Journal of Financial Economics, 83, 531-569.

Shimer, R. (2009): “Convergence in Macroeconomics: The Labor Wedge," American Economic Journal: Macroeconomics, 1(1), 280-297. 
Smets, F., And R. Wouters (2007): “Shocks and Frictions in US Business Cycles: A Bayesian DSGE Approach,” American Economic Review, 97(3), 586-606. 